OPEN ACCESS

Edited by:

Hubert Vaudry,

University of Rouen, France

Reviewed by:

Troadec Jean Denis,

Aix-Marseille University, France

Julie A. Chowen,

Hospital Infantil Universitario Niño

Jesús, Spain

*Correspondence:

Denis Richard

denis.richard@criucpq.ulaval.ca

Specialty section:

This article was submitted to Neuroendocrine Science,

a section of the journal

Frontiers in Neuroscience

Received: 15 February 2017 Accepted: 24 May 2017

Published: 23 June 2017

Citation:

Lanfray D and Richard D (2017)

Emerging Signaling Pathway in Arcuate Feeding-Related Neurons:

Role of the Acbd7.

Front. Neurosci. 11:328.

doi: 10.3389/fnins.2017.00328

\section{Emerging Signaling Pathway in Arcuate Feeding-Related Neurons: Role of the Acbd7}

\author{
Damien Lanfray and Denis Richard * \\ Centre de Recherche de l'Institut Universitaire de Cardiologie et de Pneumologie de Québec, Université Laval, Québec, QC, \\ Canada
}

The understanding of the mechanisms whereby energy balance is regulated is essential to the unraveling of the pathophysiology of obesity. In the last three decades, focus was put on the metabolic role played by the hypothalamic neurons expressing proopiomelanocortin (POMC) and cocaine and amphetamine regulated transcript (CART) and the neurons co-localizing agouti-related peptide (AgRP), neuropeptide $Y$ (NPY), and gamma-aminobutyric acid (GABA). These neurons are part of the leptin-melanocortin pathway, whose role is key in energy balance regulation. More recently, the metabolic involvement of further hypothalamic uncharacterized neuron populations has been suggested. In this review, we discuss the potential homeostatic implication of hypothalamic GABAergic neurons that produce Acyl-Coa-binding domain containing protein 7 (ACBD7), precursor of the nonadecaneuropeptide (NDN), which has recently been characterized as a potent anorexigenic neuropeptide capable of relaying the leptin anorectic/thermogenic effect via the melanocortin system.

\section{Keywords: hypothalamus, leptin, POMC, ACBD7, food intake behavior}

\section{INTRODUCTION}

According to the World Health Organization (http://www.who.int/mediacentre/factsheets/fs311/ en/) worldwide obesity prevalence has more than doubled since 1980. This situation is alarming given that obesity is often associated with costly diseases that include type- 2 diabetes and cardiovascular diseases. In such a context, it appears urgent to improve the strategies to prevent or treat obesity, which cannot be elaborated without a deep understanding of the pathophysiology of excess fat deposition, hence the mechanisms whereby energy balance is regulated.

Obesity translates an imbalance between energy intake and energy expenditure leading to fat accumulation. In that respect, study of the causes of excess eating represents an inescapable step to understand obesity. Food intake as well as and energy expenditure are controlled by complex brain networks involving (i) cortical executive circuits, responsible for the self-control of eating and physical activity, (ii) corticolimbic reward pathways, which are involved in the integrations of hedonic and motivational signals, and (iii) autonomic hypothalamic and brainstem circuits that modulate the activity of the executive and reward structures while integrating peripheral homeostatic signals and controlling energy expenditure components (Gautron et al., 2015; Richard, 2015; Caron and Richard, 2017). Neurons of those networks produce numerous receptor types, neuropeptides and neurotransmitters that have been grouped into "pro-anabolic" (promoting obesity) or "pro-catabolic" (preventing obesity) chemical mediators. 


\section{AUTONOMIC REGULATION OF ENERGY HOMEOSTASIS}

The autonomic circuits regulating energy balance mainly consist in two brain structures, namely the hypothalamus and brainstem, which coordinate their respective activity to control energy intake, by modulating the rostral forebrain appetite network (executive and reward systems), and to control energy expenditure, by for instance modulating brown adipose tissue (BAT) non-shivering thermogenesis. Due to their anatomic locations, hypothalamic and brainstem neurons of those two regions are able of sensing homeostatic hormones and nutrients translating energy balance fluctuations. Notably, the hypothalamus and brainstem are located near to circumventricular organs (CVOs), which are devoid of blood brain barrier allowing direct contact with nutrients and hormones (Schwartz et al., 2000).

The hypothalamus is constituted of nuclei comprising neurons involved in autonomic functions including the control of energy intake and energy expenditure (Gautron et al., 2015; Richard, 2015; Caron and Richard, 2017). Those neurons, which are still to be fully characterized are located in nuclei including the arcuate nucleus (ARC), ventromedial nucleus $(\mathrm{VMH})$, dorsomedial hypothalamic nucleus $(\mathrm{DMH})$, lateral hypothalamus $(\mathrm{LH})$, preoptic area (POA), and paraventricular hypothalamic nucleus (PVH) (Schwartz et al., 2000). They for instance convey homeostatic signals between the hypothalamus and appetitive rostral forebrain systems (Gautron et al., 2015; Richard, 2015; Caron and Richard, 2017). The brainstem comprises the dorsal vagal complex (DVC), which includes interconnected neurons found in the nucleus of the solitary tract (NTS), area postrema (AP), and dorsal motor nucleus of the vagus nerve (Blevins and Baskin, 2010; Schwartz, 2010; Simpson and Bloom, 2010). Other brainstem structures including the pontine parabrachial nucleus $(\mathrm{PBN})$, raphe pallidus $(\mathrm{RPa})$, periaqueductal gray (PAG), and lateral paragigantocellular nucleus have been associated with SNS-mediated non-shivering thermogenesis, by mainly conveying information from the hypothalamus to the interscapular brown adipose tissue (iBAT) (Morrison and Nakamura, 2011).

\section{The ARC in Energy Homeostasis}

The hypothalamic nucleus that has been the most investigated in recent years with regard to energy homeostasis is undoubtedly the ARC (Gautron et al., 2015; Richard, 2015; Caron and Richard, 2017). The ARC is ventrally located on each side of the third ventricle just above the median eminence, a CVO allowing penetrance of peripheral hormones and nutrients (Schwartz et al., 2000; Richard, 2015). The ARC contains neurons producing proopiomelanocortin (POMC) and cocaine and amphetamine regulated transcript (CART) as well as neurons co-localizing agouti-related peptide (AgRP), neuropeptide Y (NPY), and gamma-aminobutyric acid (GABA), whose role in energy balance regulation have been acknowledged for years (Gropp et al., 2005; Luquet et al., 2005; Mayer and Belsham, 2009; Krashes et al., 2013). The NPY/AgRP/GABA- producing neurons exert anabolic effects while POMC/CART neurons are involved in catabolic processes. Those neurons have been referred to as "first order" neurons and project to "second order" neurons located in energy homeostasis-related nuclei, including the $\mathrm{PVH}$ and $\mathrm{VMH}$, which individually form with the ARC prominent duets in the regulation of energy balance (Schwartz et al., 2000; Balthasar et al., 2005; Elmquist et al., 2005; Balthasar, 2006; Morton et al., 2006; Richard, 2015). Recently, single cell analysis performed in the hypothalamus revealed an important heterogeneity of ARC cells (Romanov et al., 2017), indicating that additional investigations will have to be make in order to fully characterized hypothalamic regulations of whole body homeostasis.

\section{The Melanocortin System}

ARC POMC/CART and NPY/AgRP/GABA neurons are major constituents of the melanocortin system, which is recognized as playing a genuine role in energy balance regulation (Adan et al., 2006; Butler, 2006; Cone, 2006; Ellacott and Cone, 2006; De Jonghe et al., 2011; Xu et al., 2011). POMC/CART neurons exert their hypophagic and thermogenic effects mainly by releasing the melanocortins $\alpha$ - and $\beta$-melanocyte-stimulating hormone (MSHs). $\alpha$ - and $\beta$-MSHs activate the melanocortin receptors 3 and 4 (MC3R, MC4R) to increase food intake and reduce energy expenditure (Cone, 2006). Interestingly, recent report indicate that $\mathrm{POMC}$ neurons are also able to released $\beta$-endorphin instead of $\mathrm{MSH}$ indicating that those neurons should also act as orexigenic neurons (Koch et al., 2015). However, investigations performed on POMC knockout revealed morbid obesity resulting from hyperphagia as well as hypometabolism (Yaswen et al., 1999), indicating that POMC neurons mainly act as anorexigenic neurons. While the Mc4r knockout mice exhibit marked obesity, resulting from hyperphagia and hypometabolism (Huszar et al., 1997; Butler and Cone, 2003; Butler, 2006), genetic disruption of the Mc3r lead to a modest obesity phenotype (Chen et al., 2000; Butler and Cone, 2002, 2003), suggesting that MC4R constitutes the major MCR receptor involved in energy homeostasis. The prominent role of $\mathrm{Mc} 4 \mathrm{r}$ in the hypothalamic regulation of energy balance has been confirmed in humans, in whom the Mc4r mutation leads to one of the most common forms of monogenic obesity (Coll et al., 2004).

NPY/AgRP/GABA neurons are also part of the melanocortin system. Together with inhibiting the activity of the POMC/CART neurons through a GABAergic effect (Pu et al., 1999), they release AgRP, a characterized anabolic peptide able to competitively inhibit $\alpha-\mathrm{MSH}$ binding to the MC4R (Ollmann et al., 1997). AgRP has also recently been described as a biased agonist of MCR coupling to the inwardly rectifying potassium channel Kir7.1 (Ghamari-Langroudi et al., 2015). AgRP production is increased by fasting (Liu et al., 2012), supporting a physiological role for this peptide in the ARC control of energy homeostasis. Interestingly, non-conditional single $\mathrm{KO} \mathrm{AgRP}^{-/-}$as well as double $\mathrm{KO} \mathrm{AgRP}^{-/-} ; \mathrm{NPY}^{-/-}$display normal energy homeostasis (Qian et al., 2002), suggesting that NPY/AgRP neurons are dispensable in the hypothalamic control of energy homeostasis. However, the post-natal genetic disruption of AgRP induces hypermetabolism and hypophagia (Luquet et al., 2005), demonstrating some physiological relevance of the neuron 
population. NPY has been considered as a robust orexigenic neuropeptide mainly by acting on Y1 and Y5 receptors (Richard, 2015). Interestingly, experiments performed in mice have indicated that the deletion of both Y1 and Y5 receptors induces anorexigenic effects (Nguyen et al., 2012), suggesting that Y1 and $\mathrm{Y} 5$ are receptors involved in energy balance. In contrast, the genetic disruption of $N p y$ does not produce a lean phenotype or does not increase fasting-induced food intake, suggesting that Npy is not essential to the hypothalamic control of energy homeostasis. On the other hand, several investigations performed on Npy knockout mice revealed that those mice are less sensitive to high fat diet (Patel et al., 2006) (ref) and leptin (Erickson et al., 1996), which suggest that NPY could play a significant role in the hypothalamic integration of homeostatic signals. In that regard, future investigations appear require to further entirely decipher the role of NPY and its receptor in regulation of energy homeostasis.

\section{The ARC as a Relay for Peripheral Homeostatic Signals}

As alluded to above, ARC cells, including POMC/CART and NPY/AgRP/GABA neurons, are strategically located to act as relays between peripheral homeostatic signals and other hypothalamic circuits involved in energy balance. The homeostatic signals can be anabolic and catabolic circulating hormones and nutrients.

Among all characterized anabolic hormones, ghrelin has emerged as one of the most significant ones. Ghrelin, which is largely produced by stomach cells under fasting (Sanchez et al., 2004a,b; Vallejo-Cremades et al., 2004), promotes food intake and decreases energy expenditure (Ueno et al., 2005) by acting on the growth hormone secretagogue receptor type 1A (GHS-R) (Kim et al., 2003; Egecioglu et al., 2006; Bresciani et al., 2008). The physiological role of ghrelin in the energy homeostasis is supported by investigations performed in mice revealing that genetic disruption of Ghrelin or Ghs-r can prevent high-fat induced obesity (Lee et al., 2016). GHS-R is widely produced in the central nervous system, where ghrelin exerts its effects in several brain regions (Zigman et al., 2006). Furthermore, experiments performed in GHS-R-deficient mice have shown that specific re-expression of the GHS-R in ARC AgRP neurons partially restores the orexigenic effect of the ghrelin (Wang et al., 2014), which confirms the involvement of AgRP-producing neurons as relays in the hypothalamic ghrelin signaling pathway.

Among all key homeostatic hormones, leptin, which is produced mainly by white adipose tissue (MacDougald et al., 1995; Cinti et al., 1997; Niijima, 1998) (WAT), is considered as one of the most prominent catabolic circulating hormones (Elmquist et al., 1997; Friedman and Halaas, 1998; Elias et al., 1999; Friedman, 1999; Gautron et al., 2010; Gautron and Elmquist, 2011). Leptin levels increase with fat mass (Lonnqvist et al., 1997). Its access to the brain is insured by an active transport system apparently involving tanycytes (Balland and Prevot, 2014; Balland et al., 2014). Leptin acts by activating the LepRb receptor, which can be found in several populations of ARC cells including POMC/CART and NPY/AgRP/GABA neurons. Genetic disruption of the gene encoding leptin $(o b)$ or its receptor (Lepr) leads to marked obesity, hyperphagia and reduced BAT thermogenesis in mice (Thenen and Mayer, 1976; Leiter et al., 1983; Garris, 1987, 1989; Malik and Young, 1996; Mizuno et al., 1998; Garris and Garris, 2004; Goncalves et al., 2009).

Notably, the obesity induced by the disruption of leptin signaling resembles that observed following Pomc or $\mathrm{Mc} 4 \mathrm{r}$ nullification (Trevaskis and Butler, 2005). In such context one may argue the presence of a functional link between leptin and the melanocortin system, all the more so that POMC/CART and NPY/AgRP/GABA neurons express LepR mRNA (Baskin et al., 1999; Elias et al., 1999; Wilson et al., 1999; Williams et al., 2010) and that leptin increases and decreases the mRNA levels of Agrp and Pomc respectively (Elias et al., 1999; Cowley et al., 2001; van den Top et al., 2004; Takahashi and Cone, 2005). However, experiments performed in mice revealed that mice lacking Lepr on POMC neurons (e.g., Pomc-Cre, Lepr $r^{\text {lox } / l o x}$ mice) (Balthasar et al., 2004), on AgRP neurons (e.g., Agrp-Cre, Leprox/lox mice) (Tong et al., 2008) and on both POMC and AgRP neurons (e.g., Pomc-Cre, Agrp-Cre, Lepr ${ }^{\text {lox/lox }}$ mice) (van de Wall et al., 2008) develop mild obesity, which suggests that the POMC/CART and NPY/AgRP/GABA could not be the only neurons interfacing the catabolic action of leptin. In that regard, the suggestion has been made that there could exist another population of neurons involved in the hypothalamic leptin signaling pathway. In that regard, mice lacking Lepr on GABA-producing neurons (Vong et al., 2011) (Vgat-Cre, Lepr ${ }^{\text {lox/lox }}$ mice) develop strong obesity. Apparently, there are LepR-expressing GABAergic neurons, distinct from NPY/AgRP neurons that exert an inhibitory tone onto POMC neurons, which could be blunted by leptin (Vong et al., 2011). This presumption has however been challenged by experiments performed in obese model mice homozygous for the Lepr ${ }^{\mathrm{S} 1138}$ allele, in which the ability to acutely decrease the GABA inhibitory tone is unaltered, despite the loss of the catabolic effects of leptin. In such a context, the characterization of the unidentified neurons capable of modulating POMC/CART neurons in response to leptin can be seen as major challenge of the current research in the neurobiology of obesity.

\section{ARC ANORECTIC NEUROCHEMICAL CANDIDATES INTERFACING LEPTIN AND THE MELANOCORTIN SYSTEMS}

The list of ARC neuromediators other than those released by POMC/CART and NPY/AgRP/GABA neurons, which could relay the catabolic message of leptin via the melanocrotin system, is rather short. It includes prolactin-releasing peptide (PrRP), neurotensin, diazepam-binding inhibitor/acylcoA binding protein (DBI/ACBP) and acyl-coA-binding domain containing protein 7 (ACBD 7 ).

PrRP is a potent anorexigenic neuropeptide acting via the Neuropeptide FF receptor 2 (NPFF2) receptor (Engstrom et al., 2003). It is expressed by ARC neurons harboring the LEPRs (Ellacott et al., 2002). Its expression is reduced in leptin-resistant Zucker rats, suggesting that leptin can directly activate PrRP 
neurons (Ellacott et al., 2002). Moreover, a recent report revealed that PrRP was strongly enriched in LEPRs-positive neurons (Allison et al., 2015), indicating that PrRP positive neurons should play significant role in the leptin signaling pathway. However, mice lacking PrRP in LEPRs producing neurons ( $P r R P$ Cre, and Lepr flox/flox mice) only develop mild obesity mainly due to lower energy expenditure (Dodd et al., 2014), which suggests that PrRP-producing neurons do not represent a major relay between leptin and the melanocortin signaling pathway.

Neurotensin is a 13-amino acid neuropeptide produced in the ARC, PVN, and DMH (Jennes et al., 1982; Beck et al., 1998). Its injection into the PVN decreases food intake (Stanley et al., 1983) and its production is increased by leptin injection (Beck et al., 1998). However, the evidence that leptin could mainly act through the ARC neurotensin-containing neurons is weak. Indeed, mice lacking the LEPR on NT neurons (Nt-Cre, Lepr ${ }^{\text {lox/lox }}$ mice) develop only mild obesity (Leinninger et al., 2011).

The diazepam-binding inhibitor/AcylCoA binding Protein (DBI/ACBP) is a $87 / 88$ amino acid polypeptide produced by astroglial cells in the rodent hypothalamus (Tonon et al., 1990). DBI/ACBP is processed into several gliopeptides, including the octadecaneuropeptide (ODN), a potent anorexigenic peptide (de Mateos-Verchere et al., 2001; do Rego et al., 2007; Lanfray et al., 2013, 2016). Although ODN is exclusively produced by astroglial cells in the hypothalamus (Tonon et al., 1990), it can be considered as a candidate in the leptin-melanocortin pathway since astrocytes have been shown to produce LEPRs (Hsuchou et al., 2009a,b). Interestingly experiments perform in laboratory rodents indicate that the anorexigenic effect of icv injection of ODN is relayed by central activation of the MC3/4R (Lanfray et al., 2013), suggesting that ODN could directly activate POMC/CART neurons. Moreover, it has been recently demonstrated that the pharmacological disruption of the endozepine metabotropic receptor blunts the anorexigenic effect of the leptin (Lanfray et al., 2016), indicating that ODN may be involved in the leptin-melanocortin pathway. However, it has been demonstrated that the Dbi/Acbp mRNA levels are not affected by leptin in mice (Compere et al., 2010), which suggests that ODN is probably not a major component in the action of leptin on the melanocortin system.

\section{ACYL-COA-BINDING DOMAIN CONTAINING PROTEIN 7 (ACBD7) AS A NEUROMEDIATOR INVOLVED IN THE CENTRAL EFFECTS OF LEPTIN}

\section{ACDB7 Origin}

ACBD7 is a member of the ACBD protein family, which includes proteins containing the acyl-coA-binding domain motif signature (Burton et al., 2005; Neess et al., 2015). This protein family contains the well-characterized ACBD1, also known as DBI/ACBP (see above), which is known to be involved in numerous intracellular processes including fatty acid, glycerolipid, and glycerophospholipid biosynthesis, cellular differentiation and proliferation, and $\beta$-oxydation. Several hypothetical related-proteins have been characterized in silico, including ACBD7, which represents the product of a wellconserved paralog gene of the DBI/ACBP. Interestingly, sequence analysis has revealed that ACBD7 contains all the residues relevant for DBI/ACBP stability and acyl-CoA binding efficiency (Burton et al., 2005). However, while the three-dimensional conformation of the ACBD7 has been characterized (Neess et al., 2015), its ability to bind acyl-CoA esters remains to be established.

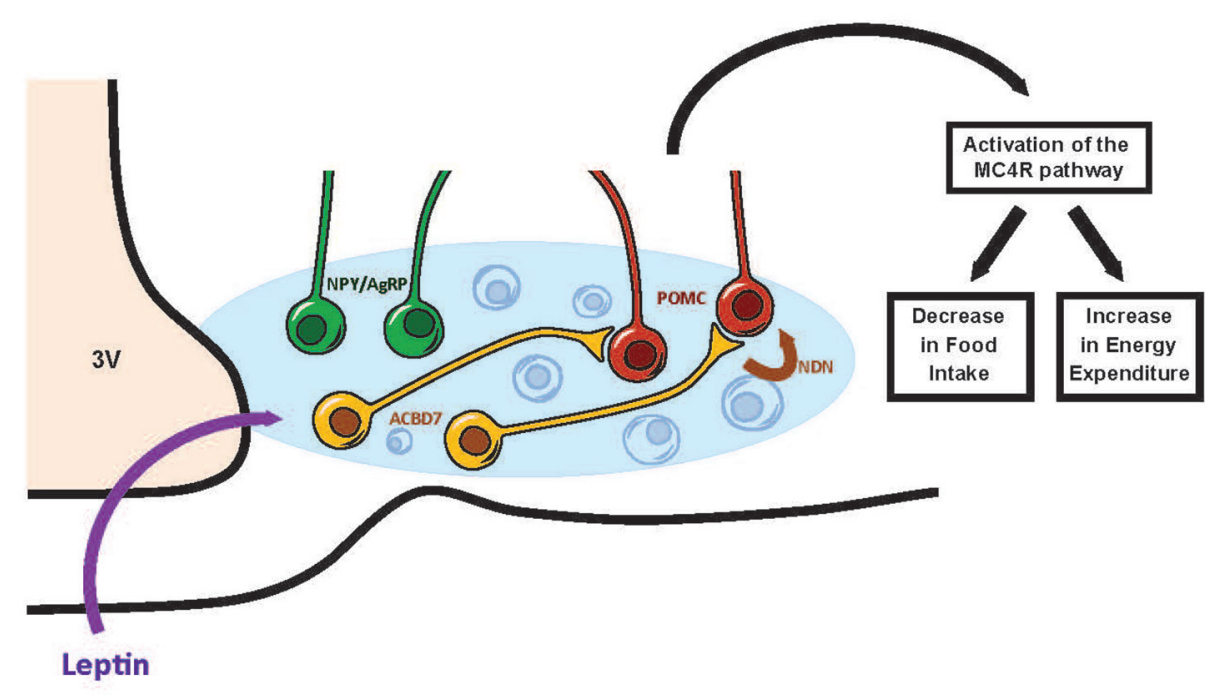

FIGURE 1 | Scheme tentatively summarizing the involvement of ACBD7 and its related product NDN in the effects of leptin in the ARC. According to this scheme, ACBD7-producing neurons would release NDN in response to an increase of leptin (Leptin) concentrations and stimulate the activity of POMC neurons. Activation of POMC neurons of the ARC would lead to the activation of the melanocortin signaling pathway and subsequently to a decrease in food intake and an increase in energy expenditure. 
Considering the highly conserved exon/intron structure (Lanfray et al., 2016) of Acbd7, it has been postulated that the duplication of the ancestor gene occurs prior to the divergence of fish and higher vertebrates (450 Mya) (Burton et al., 2005). Interestingly, as for its paralog gene product (i.e., Dbi/Acbp), ACBD7 contains strongly conserved lysine allowing for the production of potential bioactive peptides, including a potential bioactive central fragment, released from a tryptic maturation process. By using a mass spectrometry-multiple reaction monitoring MS-MRM approach, we demonstrated that a 19-amino acid peptidederived from ACBD7 (called nonadecaneuropeptide-NDN) was present in the mouse hypothalamus, demonstrating that Acbd7 was produced and processed in vivo (Lanfray et al., 2016).

The expression of Acbd7 in the hypothalamus suggests that ACBD7 may exert specific autonomic functions (Neess et al., 2015). We recently confirmed that Acbd7 was expressed by ARC and PVN neurons (Lanfray et al., 2016), two structures described above as key in the hypothalamic regulation of energy balance. Additionally, immunohistochemistry experiments have shown that ACBD7 is produced by ARC neuronal cells apparently differing from NPY/AgRP/GABA and POMC/CART (Lanfray et al., 2016). Additionally, our investigation indicates that ACBD7 immunoreactivity is co-localized with VGAT immuno-labeling (Lanfray et al., 2016), demonstrating that ACBD7 is produced by GABAergic neurons in the hypothalamus.

\section{Effects of ACBD7 on Energy Homeostasis}

The observation that ARC ACBD7 produced a fragment homologous to the anorexigenic DBI/ACBP-derived peptide ODN prompted us to hypothesize that ACBD7-containing neurons could be involved in energy balance, all the more so that there existed a $A c b d 7$ polymorphism that had been associated to obesity in humans (Comuzzie et al., 2012).

To determine the role of ACBD7 on energy homeostasis, we assessed the effects of NDN on both food intake and energy expenditure. Our investigations performed in mice revealed that intracerebroventricular (icv) administration of NDN induced an early and marked inhibition of food intake in fasted mice (Lanfray et al., 2016). Our investigations also demonstrated that the icv injection of NDN increased both $\mathrm{O}_{2}$ consumption and UCP-1 expression in interscapular BAT (Lanfray et al., 2016), suggesting that NDN could also enhance energy expenditure. We also observed that the subchronic treatment with NDN ( 5 days) reduced food efficiency. Notably, the anorexigenic effect of NDN was blunted by the antagonism of the MC4R (Lanfray et al., 2016), the main effector of the melanocortin signaling pathway, suggesting that NDN acted upstream to the melanocortin signaling pathway.

We also demonstrated that Acbd7 mRNA levels, the ACBD7 protein levels and hypothalamic NDN levels varied with energy availability (Lanfray et al., 2016). This supports the notion that
ACBD7-producing neurons are stimulated by one or several catabolic hormones/factors. In that regard, we demonstrated that the leptin treatment could increase the production of both ACBD7 and NDN, suggesting that leptin is able to stimulate ACBD7-producing neurons (Lanfray et al., 2016). Moreover, we demonstrated that the acute pharmacological disruption of the endozepines metabotropic receptor signaling blunted the anorexigenic effect of leptin (Lanfray et al., 2016).

Altogether the data accumulated so far suggest that (i) ACBD7 and NDN are produced by ARC GABAergic neurons different from POMC/CART and NPY/AgRP/GABA neurons, (ii) $\mathrm{NDN}$ is a anorexigenic peptide acting probably via the activation of ARC POMC/CART neurons, and (iii) NDN signaling contributes to the leptin-melanocortin pathway. While the identity of the uncharacterized endozepine metabotropic receptor remains to be fully established, we can postulate that the ARC ACBD7 producing neuron represents a significant relay between leptin and the melanocortin signaling pathway.

\section{CONCLUSION}

This review has focused on the recent discoveries regarding the hypothalamic leptin signaling pathway and on potential ARC anorectic neurochemical candidates interfacing leptin of the melanocortin system. Up until recently, it was though that leptin action on ARC POMC/CART and NPY/AgRP/GABA neurons was essentially mediated through the leptin receptors (LepR) found on those neurons (Elias et al., 1999; Balthasar et al., 2004; Zhang and Scarpace, 2006). However, recent data have indicated that the leptin effect on the melanocortin system can be relayed by an uncharacterized class of ARC neurons that are distinct from POMC/CART and NPY/AgRP/GABA neurons (Balthasar et al., 2004; van de Wall et al., 2008; Hill et al., 2010; Vong et al., 2011). In this context, the identification of ARC neuromediators other than those released by the POMC/CART and NPY/AgRP/GABA neurons that could relay the catabolic message of leptin via the melanocortin system, appeared justified in our understanding of the pathophysiology of obesity. We identified ARC ACBD7 and its anorexigenic maturation product NDN as playing a role in energy homeostasis. NDN acts mainly by stimulating the melanocortin signaling pathway while NDN signaling disruption blunts the anorexigenic effects of leptin (Figure 1). Future investigations to further examine the involvement of ACBD7 production by ARC Lepr-producing neurons in the hypothalamic leptin signaling pathway appear warranted.

\section{AUTHOR CONTRIBUTIONS}

DL contributed to manuscript preparation and manuscript definition of intellectual content. DR also contributed to manuscript preparation and followed by manuscript editing and revision. 


\section{REFERENCES}

Adan, R. A., Tiesjema, B., Hillebrand, J. J., la Fleur, S. E., Kas, M. J., and de Krom, M. (2006). The MC4 receptor and control of appetite. Br. J. Pharmacol. 149, 815-827. doi: 10.1038/sj.bjp.0706929

Allison, M. B., Patterson, C. M., Krashes, M. J., Lowell, B. B., Myers, M. G., and Olson, D. P. (2015). TRAP-seq defines markers for novel populations of hypothalamic and brainstem LepRb neurons. Mol. Metab. 4, 299-309. doi: 10.1016/j.molmet.2015.01.012

Balland, E., Dam, J., Langlet, F., Caron, E., Steculorum, S., Messina, A., et al. (2014). Hypothalamic tanycytes are an ERK-gated conduit for leptin into the brain. Cell Metab. 19, 293-301. doi: 10.1016/j.cmet.2013.12.015

Balland, E., and Prevot, V. (2014). [Tanycytes gate leptin transport into the hypothalamus]. Med. Sci. 30, 624-627. doi: 10.1051/medsci/20143006009

Balthasar, N. (2006). Genetic dissection of neuronal pathways controlling energy homeostasis. Obesity (Silver Spring) 14(Suppl. 5), 222S-227S. doi: 10.1038/oby.2006.313

Balthasar, N., Coppari, R., McMinn, J., Liu, S. M., Lee, C. E., Tang, V., et al. (2004). Leptin receptor signaling in POMC neurons is required for normal body weight homeostasis. Neuron 42, 983-991. doi: 10.1016/j.neuron.2004.06.004

Balthasar, N., Dalgaard, L. T., Lee, C. E., Yu, J., Funahashi, H., Williams, T., et al. (2005). Divergence of melanocortin pathways in the control of food intake and energy expenditure. Cell 123, 493-505. doi: 10.1016/j.cell.2005.08.035

Baskin, D. G., Breininger, J. F., and Schwartz, M. W. (1999). Leptin receptor mRNA identifies a subpopulation of neuropeptide $Y$ neurons activated by fasting in rat hypothalamus. Diabetes 48, 828-833. doi: 10.2337/diabetes.48.4.828

Beck, B., Stricker-Krongrad, A., Richy, S., and Burlet, C. (1998). Evidence that hypothalamic neurotensin signals leptin effects on feeding behavior in normal and fat-preferring rats. Biochem. Biophys. Res. Commun. 252, 634-638. doi: 10.1006/bbrc.1998.9712

Blevins, J. E., and Baskin, D. G. (2010). Hypothalamic-brainstem circuits controlling eating. Forum Nutr. 63, 133-140. doi: 10.1159/000264401

Bresciani, E., Tamiazzo, L., Torsello, A., Bulgarelli, I., Rapetti, D., Caporali, S., et al. (2008). Ghrelin control of GH secretion and feeding behaviour: the role of the GHS-R1a receptor studied in vivo and in vitro using novel non-peptide ligands. Eat. Weight Disord. 13, e67-e74.

Burton, M., Rose, T. M., Faergeman, N. J., and Knudsen, J. (2005). Evolution of the acyl-CoA binding protein (ACBP). Biochem. J. 392, 299-307. doi: 10.1042/BJ20050664

Butler, A. A. (2006). The melanocortin system and energy balance. Peptides 27, 281-290. doi: 10.1016/j.peptides.2005.02.029

Butler, A. A., and Cone, R. D. (2002). The melanocortin receptors: lessons from knockout models. Neuropeptides 36, 77-84. doi: 10.1054/npep.2002.0890

Butler, A. A., and Cone, R. D. (2003). Knockout studies defining different roles for melanocortin receptors in energy homeostasis. Ann. N. Y. Acad. Sci. 994, 240-245. doi: 10.1111/j.1749-6632.2003.tb03186.x

Caron, A., and Richard, D. (2017). Neuronal systems and circuits involved in the control of food intake and adaptive thermogenesis. Ann. N. Y. Acad. Sci. 1391, 35-53. doi: 10.1111/nyas.13263

Chen, A. S., Marsh, D. J., Trumbauer, M. E., Frazier, E. G., Guan, X. M., Yu, $\mathrm{H}$., et al. (2000). Inactivation of the mouse melanocortin-3 receptor results in increased fat mass and reduced lean body mass. Nat. Genet. 26, 97-102. doi: $10.1038 / 79254$

Cinti, S., Frederich, R. C., Zingaretti, M. C., De Matteis, R., Flier, J. S., and Lowell, B. B. (1997). Immunohistochemical localization of leptin and uncoupling protein in white and brown adipose tissue. Endocrinology 138, 797-804. doi: 10.1210/endo.138.2.4908

Coll, A. P., Farooqi, I. S., Challis, B. G., Yeo, G. S., and O'Rahilly, S. (2004). Proopiomelanocortin and energy balance: insights from human and murine genetics. J. Clin. Endocrinol. Metab. 89, 2557-2562. doi: 10.1210/jc.2004-0428

Compere, V., Lanfray, D., Castel, H., Morin, F., Leprince, J., Dureuil, B., et al. (2010). Acute food deprivation reduces expression of diazepam-binding inhibitor, the precursor of the anorexigenic octadecaneuropeptide ODN, in mouse glial cells. J. Mol. Endocrinol. 44, 295-299. doi: 10.1677/JME-09-0176

Comuzzie, A. G., Cole, S. A., Laston, S. L., Voruganti, V. S., Haack, K., Gibbs, R. A., et al. (2012). Novel genetic loci identified for the pathophysiology of childhood obesity in the Hispanic population. PLoS ONE 7:e51954. doi: 10.1371/journal.pone.0051954
Cone, R. D. (2006). Studies on the physiological functions of the melanocortin system. Endocr. Rev. 27, 736-749. doi: 10.1210/er.2006-0034

Cowley, M. A., Smart, J. L., Rubinstein, M., Cerdan, M. G., Diano, S., Horvath, T. L., et al. (2001). Leptin activates anorexigenic POMC neurons through a neural network in the arcuate nucleus. Nature 411, 480-484. doi: 10.1038/35078085

De Jonghe, B. C., Hayes, M. R., and Bence, K. K. (2011). Melanocortin control of energy balance: evidence from rodent models. Cell. Mol. Life Sci. 68, 2569-2588. doi: 10.1007/s00018-011-0707-5

de Mateos-Verchere, J. G., Leprince, J., Tonon, M. C., Vaudry, H., and Costentin, J. (2001). The octadecaneuropeptide [diazepam-binding inhibitor (33-50)] exerts potent anorexigenic effects in rodents. Eur. J. Pharmacol. 414, 225-231. doi: 10.1016/S0014-2999(01)00771-3

Dodd, G. T., Worth, A. A., Nunn, N., Korpal, A. K., Bechtold, D. A., Allison, M. B., et al. (2014). The thermogenic effect of leptin is dependent on a distinct population of prolactin-releasing peptide neurons in the dorsomedial hypothalamus. Cell Metab. 20, 639-649. doi: 10.1016/j.cmet.2014.07.022

Egecioglu, E., Bjursell, M., Ljungberg, A., Dickson, S. L., Kopchick, J. J., Bergstrom, G., et al. (2006). Growth hormone receptor deficiency results in blunted ghrelin feeding response, obesity, and hypolipidemia in mice. Am. J. Physiol. Endocrinol. Metab. 290, E317-E325. doi: 10.1152/ajpendo.00181.2005

Elias, C. F., Aschkenasi, C., Lee, C., Kelly, J., Ahima, R. S., Bjorbaek, C., et al. (1999). Leptin differentially regulates NPY and POMC neurons projecting to the lateral hypothalamic area. Neuron 23, 775-786. doi: 10.1016/S0896-6273(01)80035-0

Ellacott, K. L., and Cone, R. D. (2006). The role of the central melanocortin system in the regulation of food intake and energy homeostasis: lessons from mouse models. Philos. Trans. R. Soc. Lond. B Biol. Sci. 361, 1265-1274. doi: $10.1098 /$ rstb.2006.1861

Ellacott, K. L., Lawrence, C. B., Rothwell, N. J., and Luckman, S. M. (2002). PRLreleasing peptide interacts with leptin to reduce food intake and body weight. Endocrinology 143, 368-374. doi: 10.1210/endo.143.2.8608

Elmquist, J. K., Ahima, R. S., Maratos-Flier, E., Flier, J. S., and Saper, C. B. (1997). Leptin activates neurons in ventrobasal hypothalamus and brainstem. Endocrinology 138, 839-842. doi: 10.1210/endo.138.2.5033

Elmquist, J. K., Coppari, R., Balthasar, N., Ichinose, M., and Lowell, B. B. (2005). Identifying hypothalamic pathways controlling food intake, body weight, and glucose homeostasis. J. Comp. Neurol. 493, 63-71. doi: 10.1002/cne.20786

Engstrom, M., Brandt, A., Wurster, S., Savola, J. M., and Panula, P. (2003). Prolactin releasing peptide has high affinity and efficacy at neuropeptide FF2 receptors. J. Pharmacol. Exp. Ther. 305, 825-832. doi: 10.1124/jpet.102.047118

Erickson, J. C., Clegg, K. E., and Palmiter, R. D. (1996). Sensitivity to leptin and susceptibility to seizures of mice lacking neuropeptide Y. Nature 381, 415-421. doi: $10.1038 / 381415 \mathrm{a} 0$

Friedman, J. M. (1999). Leptin and the regulation of body weight. Harvey Lect. 95, 107-136.

Friedman, J. M., and Halaas, J. L. (1998). Leptin and the regulation of body weight in mammals. Nature 395, 763-770. doi: 10.1038/27376

Garris, D. R. (1987). Obese (ob/ob) and diabetes (db/db) mutations: two factors modulating brain and peripheral tissue accumulation of estradiol in C57BL/KsJ mice. Brain Res. 432, 153-157. doi: 10.1016/0165-3806(87)90018-6

Garris, D. R. (1989). Morphometric analysis of obesity (ob/ob)- and diabetes (db/db)-associated hypothalamic neuronal degeneration in C57BL/KsJ mice. Brain Res. 501, 162-170. doi: 10.1016/0006-8993(89)91037-8

Garris, D. R., and Garris, B. L. (2004). Genomic modulation of diabetes (db/db) and obese (ob/ob) mutation-induced hypercytolipidemia: cytochemical basis of female reproductive tract involution. Cell Tissue Res. 316, 233-241. doi: 10.1007/s00441-004-0863-0

Gautron, L., and Elmquist, J. K. (2011). Sixteen years and counting: an update on leptin in energy balance. J. Clin. Invest. 121, 2087-2093. doi: 10.1172/JCI45888

Gautron, L., Elmquist, J. K., and Williams, K. W. (2015). Neural control of energy balance: translating circuits to therapies. Cell 161, 133-145. doi: 10.1016/j.cell.2015.02.023

Gautron, L., Lazarus, M., Scott, M. M., Saper, C. B., and Elmquist, J. K. (2010). Identifying the efferent projections of leptin-responsive neurons in the dorsomedial hypothalamus using a novel conditional tracing approach. $J$. Comp. Neurol. 518, 2090-2108. doi: 10.1002/cne.22323

Ghamari-Langroudi, M., Digby, G. J., Sebag, J. A., Millhauser, G. L., Palomino, R., Matthews, R., et al. (2015). G-protein-independent coupling of MC4R to Kir7.1 in hypothalamic neurons. Nature 520, 94-98. doi: 10.1038/nature14051 
Goncalves, A. C., Tank, J., Diedrich, A., Hilzendeger, A., Plehm, R., Bader, M., et al. (2009). Diabetic hypertensive leptin receptor-deficient $\mathrm{db} / \mathrm{db}$ mice develop cardioregulatory autonomic dysfunction. Hypertension 53, 387-392. doi: 10.1161/HYPERTENSIONAHA.108.124776

Gropp, E., Shanabrough, M., Borok, E., Xu, A. W., Janoschek, R., Buch, T., et al. (2005). Agouti-related peptide-expressing neurons are mandatory for feeding. Nat. Neurosci. 8, 1289-1291. doi: 10.1038/nn1548

Hill, J. W., Elias, C. F., Fukuda, M., Williams, K. W., Berglund, E. D., Holland, W. L., et al. (2010). Direct insulin and leptin action on pro-opiomelanocortin neurons is required for normal glucose homeostasis and fertility. Cell Metab. 11, 286-297. doi: 10.1016/j.cmet.2010.03.002

Hsuchou, H., He, Y., Kastin, A. J., Tu, H., Markadakis, E. N., Rogers, R. C., et al. (2009a). Obesity induces functional astrocytic leptin receptors in hypothalamus. Brain 132, 889-902. doi: 10.1093/brain/awp029

Hsuchou, H., Pan, W., Barnes, M. J., and Kastin, A. J. (2009b). Leptin receptor mRNA in rat brain astrocytes. Peptides 30, 2275-2280. doi: 10.1016/j.peptides.2009.08.023

Huszar, D., Lynch, C. A., Fairchild-Huntress, V., Dunmore, J. H., Fang, Q., Berkemeier, L. R., et al. (1997). Targeted disruption of the melanocortin-4 receptor results in obesity in mice. Cell 88, 131-141. doi: 10.1016/S0092-8674(00)81865-6

Jennes, L., Stumpf, W. E., and Kalivas, P. W. (1982). Neurotensin: topographical distribution in rat brain by immunohistochemistry. J. Comp. Neurol. 210, 211-224. doi: 10.1002/cne.902100302

Kim, M. S., Yoon, C. Y., Park, K. H., Shin, C. S., Park, K. S., Kim, S. Y., et al. (2003). Changes in ghrelin and ghrelin receptor expression according to feeding status. Neuroreport 14, 1317-1320. doi: 10.1097/00001756-200307180-00006

Koch, M., Varela, L., Kim, J. G., Kim, J. D., Hernandez-Nuno, F., Simonds, S. E., et al. (2015). Hypothalamic POMC neurons promote cannabinoid-induced feeding. Nature 519, 45-50. doi: 10.1038/nature14260

Krashes, M. J., Shah, B. P., Koda, S., and Lowell, B. B. (2013). Rapid versus delayed stimulation of feeding by the endogenously released AgRP neuron mediators GABA, NPY, and AgRP. Cell Metab. 18, 588-595. doi: 10.1016/j.cmet.2013.09.009

Lanfray, D., Arthaud, S., Ouellet, J., Compere, V., Do Rego, J. L., Leprince, J., et al. (2013). Gliotransmission and brain glucose sensing: critical role of endozepines. Diabetes 62, 801-810. doi: 10.2337/db11-0785

Lanfray, D., Caron, A., Roy, M. C., Laplante, M., Morin, F., Leprince, J., et al. (2016). Involvement of the Acyl-CoA binding domain containing 7 in the control of food intake and energy expenditure in mice. Elife 5:e11742. doi: 10.7554/elife. 11742

Lee, J. H., Lin, L., Xu, P., Saito, K., Wei, Q., Meadows, A. G., et al. (2016). Neuronal deletion of ghrelin receptor almost completely prevents diet-induced obesity. Diabetes 65, 2169-2178. doi: 10.2337/db15-1587

Leinninger, G. M., Opland, D. M., Jo, Y. H., Faouzi, M., Christensen, L., Cappellucci, L. A., et al. (2011). Leptin action via neurotensin neurons controls orexin, the mesolimbic dopamine system and energy balance. Cell Metab. 14, 313-323. doi: 10.1016/j.cmet.2011.06.016

Leiter, E. H., Coleman, D. L., Ingram, D. K., and Reynolds, M. A. (1983). Influence of dietary carbohydrate on the induction of diabetes in $\mathrm{C} 57 \mathrm{BL} / \mathrm{Ks}$ - $-\mathrm{db} / \mathrm{db}$ diabetes mice. J. Nutr. 113, 184-195.

Liu, T., Kong, D., Shah, B. P., Ye, C., Koda, S., Saunders, A., et al. (2012). Fasting activation of AgRP neurons requires NMDA receptors and involves spinogenesis and increased excitatory tone. Neuron 73, 511-522. doi: 10.1016/j.neuron.2011.11.027

Lonnqvist, F., Wennlund, A., and Arner, P. (1997). Relationship between circulating leptin and peripheral fat distribution in obese subjects. Int. J. Obes. Relat. Metab. Disord. 21, 255-260. doi: 10.1038/sj.ijo.0800394

Luquet, S., Perez, F. A., Hnasko, T. S., and Palmiter, R. D. (2005). NPY/AgRP neurons are essential for feeding in adult mice but can be ablated in neonates. Science 310, 683-685. doi: 10.1126/science. 1115524

MacDougald, O. A., Hwang, C. S., Fan, H., and Lane, M. D. (1995). Regulated expression of the obese gene product (leptin) in white adipose tissue and 3T3-L1 adipocytes. Proc. Natl. Acad. Sci. U.S.A. 92, 9034-9037. doi: $10.1073 /$ pnas.92.20.9034

Malik, K. F., and Young, W. S. III. (1996). Localization of binding sites in the central nervous system for leptin ( $\mathrm{OB}$ protein) in normal, obese (ob/ob), and diabetic (db/db) C57BL/6J mice. Endocrinology 137, 1497-1500. doi: 10.1210/endo.137.4.8625929

Mayer, C. M., and Belsham, D. D. (2009). Insulin directly regulates NPY and AgRP gene expression via the MAPK MEK/ERK signal transduction pathway in mHypoE-46 hypothalamic neurons. Mol. Cell. Endocrinol. 307, 99-108. doi: 10.1016/j.mce.2009.02.031

Mizuno, T. M., Kleopoulos, S. P., Bergen, H. T., Roberts, J. L., Priest, C. A., and Mobbs, C. V. (1998). Hypothalamic pro-opiomelanocortin mRNA is reduced by fasting and [corrected] in ob/ob and $\mathrm{db} / \mathrm{db}$ mice, but is stimulated by leptin. Diabetes 47, 294-297. doi: 10.2337/diab.47.2.294

Morrison, S. F., and Nakamura, K. (2011). Central neural pathways for thermoregulation. Front. Biosci. (Landmark Ed) 16, 74-104. doi: 10.2741/3677

Morton, G. J., Cummings, D. E., Baskin, D. G., Barsh, G. S., and Schwartz, M. W. (2006). Central nervous system control of food intake and body weight. Nature 443, 289-295. doi: 10.1038/nature05026

Neess, D., Bek, S., Engelsby, H., Gallego, S. F., and Faergeman, N. J. (2015). Longchain acyl-CoA esters in metabolism and signaling: Role of acyl-CoA binding proteins. Prog. Lipid Res. 59, 1-25. doi: 10.1016/j.plipres.2015.04.001

Nguyen, A. D., Mitchell, N. F., Lin, S., Macia, L., Yulyaningsih, E., Baldock, P. A., et al. (2012). Y1 and Y5 receptors are both required for the regulation of food intake and energy homeostasis in mice. PLoS ONE 7:e40191. doi: 10.1371/journal.pone.0040191

Niijima, A. (1998). Afferent signals from leptin sensors in the white adipose tissue of the epididymis, and their reflex effect in the rat. J. Auton. Nerv. Syst. 73, 19-25. doi: 10.1016/S0165-1838(98)00109-X

Ollmann, M. M., Wilson, B. D., Yang, Y. K., Kerns, J. A., Chen, Y., Gantz, I., et al. (1997). Antagonism of central melanocortin receptors in vitro and in vivo by agouti-related protein. Science 278, 135-138. doi: 10.1126/science.278.5335.135

Patel, H. R., Qi, Y., Hawkins, E. J., Hileman, S. M., Elmquist, J. K., Imai, Y., et al. (2006). Neuropeptide Y deficiency attenuates responses to fasting and high-fat diet in obesity-prone mice. Diabetes 55, 3091-3098. doi: 10.2337/db05-0624

Pu, S., Jain, M. R., Horvath, T. L., Diano, S., Kalra, P. S., and Kalra, S. P. (1999). Interactions between neuropeptide $\mathrm{Y}$ and gamma-aminobutyric acid in stimulation of feeding: a morphological and pharmacological analysis. Endocrinology 140, 933-940. doi: 10.1210/endo.140.2.6495

Qian, S., Chen, H., Weingarth, D., Trumbauer, M. E., Novi, D. E., Guan, X., et al. (2002). Neither agouti-related protein nor neuropeptide $\mathrm{Y}$ is critically required for the regulation of energy homeostasis in mice. Mol. Cell. Biol. 22, 5027-5035. doi: 10.1128/MCB.22.14.5027-5035.2002

do Rego, J. C., Orta, M. H., Leprince, J., Tonon, M. C., Vaudry, H., and Costentin, J. (2007). Pharmacological characterization of the receptor mediating the anorexigenic action of the octadecaneuropeptide: evidence for an endozepinergic tone regulating food intake. Neuropsychopharmacology 32, 1641-1648. doi: 10.1038/sj.npp.1301280

Richard, D. (2015). Cognitive and autonomic determinants of energy homeostasis in obesity. Nat. Rev. Endocrinol. 11, 489-501. doi: 10.1038/nrendo.2015.103

Romanov, R. A., Zeisel, A., Bakker, J., Girach, F., Hellysaz, A., Tomer, R., et al. (2017). Molecular interrogation of hypothalamic organization reveals distinct dopamine neuronal subtypes. Nat. Neurosci. 20, 176-188. doi: 10.1038/nn.4462 Sanchez, J., Oliver, P., Palou, A., and Pico, C. (2004a). The inhibition of gastric ghrelin production by food intake in rats is dependent on the type of macronutrient. Endocrinology 145, 5049-5055. doi: 10.1210/en.2004-0493

Sanchez, J., Oliver, P., Pico, C., and Palou, A. (2004b). Diurnal rhythms of leptin and ghrelin in the systemic circulation and in the gastric mucosa are related to food intake in rats. Pflugers Arch. 448, 500-506. doi: 10.1007/s00424-004-1283-4

Schwartz, G. J. (2010). Brainstem integrative function in the central nervous system control of food intake. Forum Nutr. 63, 141-151. doi: 10.1159/000264402

Schwartz, M. W., Woods, S. C., Porte, D. Jr., Seeley, R. J., and Baskin, D. G. (2000). Central nervous system control of food intake. Nature 404, 661-671. doi: $10.1038 / 35007534$

Simpson, K. A., and Bloom, S. R. (2010). Appetite and hedonism: gut hormones and the brain. Endocrinol. Metab. Clin. North Am. 39, 729-743. doi: 10.1016/j.ecl.2010.08.001

Stanley, B. G., Hoebel, B. G., and Leibowitz, S. F. (1983). Neurotensin: effects of hypothalamic and intravenous injections on eating and drinking in rats. Peptides 4, 493-500. doi: 10.1016/0196-9781(83)90054-2 
Takahashi, K. A., and Cone, R. D. (2005). Fasting induces a large, leptin-dependent increase in the intrinsic action potential frequency of orexigenic arcuate nucleus neuropeptide Y/Agouti-related protein neurons. Endocrinology 146, 1043-1047. doi: 10.1210/en.2004-1397

Thenen, S. W., and Mayer, J. (1976). Hyperinsulinemia and fat cell glycerokinase activity in obese (ob/ob) and diabetic (db/db) mice. Horm. Metab. Res. 8, 80-81. doi: 10.1055/s-0028-1095594

Tong, Q., Ye, C. P., Jones, J. E., Elmquist, J. K., and Lowell, B. B. (2008). Synaptic release of GABA by AgRP neurons is required for normal regulation of energy balance. Nat. Neurosci. 11, 998-1000. doi: 10.1038/nn.2167

Tonon, M. C., Desy, L., Nicolas, P., Vaudry, H., and Pelletier, G. (1990). Immunocytochemical localization of the endogenous benzodiazepine ligand octadecaneuropeptide (ODN) in the rat brain. Neuropeptides 15, 17-24. doi: 10.1016/0143-4179(90)90155-R

Trevaskis, J. L., and Butler, A. A. (2005). Double leptin and melanocortin-4 receptor gene mutations have an additive effect on fat mass and are associated with reduced effects of leptin on weight loss and food intake. Endocrinology 146, 4257-4265. doi: 10.1210/en.2005-0492

Ueno, H., Yamaguchi, H., Kangawa, K., and Nakazato, M. (2005). Ghrelin: a gastric peptide that regulates food intake and energy homeostasis. Regul. Pept. 126, 11-19. doi: 10.1016/j.regpep.2004.08.007

Vallejo-Cremades, M. T., Gomez-Garcia, L., Chacatas-Cortesao, M., Moreno, C., Sanchez, M., De Miguel, E., et al. (2004). Enriched protein dietmodified ghrelin expression and secretion in rats. Regul. Pept. 121, 113-119. doi: 10.1016/j.regpep.2004.04.016

van den Top, M., Lee, K., Whyment, A. D., Blanks, A. M., and Spanswick, D. (2004). Orexigen-sensitive NPY/AgRP pacemaker neurons in the hypothalamic arcuate nucleus. Nat. Neurosci. 7, 493-494. doi: 10.1038/nn1226

van de Wall, E., Leshan, R., Xu, A. W., Balthasar, N., Coppari, R., Liu, S. M., et al. (2008). Collective and individual functions of leptin receptor modulated neurons controlling metabolism and ingestion. Endocrinology 149, 1773-1785. doi: 10.1210/en.2007-1132

Vong, L., Ye, C., Yang, Z., Choi, B., Chua, S. Jr., and Lowell, B. B. (2011). Leptin action on GABAergic neurons prevents obesity and reduces inhibitory tone to POMC neurons. Neuron 71, 142-154. doi: 10.1016/j.neuron.2011.05.028
Wang, Q., Liu, C., Uchida, A., Chuang, J. C., Walker, A., Liu, T., et al. (2014). Arcuate AgRP neurons mediate orexigenic and glucoregulatory actions of ghrelin. Mol. Metab. 3, 64-72. doi: 10.1016/j.molmet.2013.10.001

Williams, K. W., Margatho, L. O., Lee, C. E., Choi, M., Lee, S., Scott, M. M., et al. (2010). Segregation of acute leptin and insulin effects in distinct populations of arcuate proopiomelanocortin neurons. J. Neurosci. 30, 2472-2479. doi: 10.1523/JNEUROSCI.3118-09.2010

Wilson, B. D., Bagnol, D., Kaelin, C. B., Ollmann, M. M., Gantz, I., Watson, S. J., et al. (1999). Physiological and anatomical circuitry between Agouti-related protein and leptin signaling. Endocrinology 140, 2387-2397. doi: 10.1210/endo.140.5.6728

Xu, Y., Elmquist, J. K., and Fukuda, M. (2011). Central nervous control of energy and glucose balance: focus on the central melanocortin system. Ann. N. Y. Acad. Sci. 1243, 1-14. doi: 10.1111/j.1749-6632.2011.06248.x

Yaswen, L., Diehl, N., Brennan, M. B., and Hochgeschwender, U. (1999). Obesity in the mouse model of pro-opiomelanocortin deficiency responds to peripheral melanocortin. Nat. Med. 5, 1066-1070. doi: 10.1038/ 12506

Zhang, Y., and Scarpace, P. J. (2006). Circumventing central leptin resistance: lessons from central leptin and POMC gene delivery. Peptides 27, 350-364. doi: 10.1016/j.peptides.2005.01.024

Zigman, J. M., Jones, J. E., Lee, C. E., Saper, C. B., and Elmquist, J. K. (2006) Expression of ghrelin receptor mRNA in the rat and the mouse brain. J. Comp. Neurol. 494, 528-548. doi: 10.1002/cne.20823

Conflict of Interest Statement: The authors declare that the research was conducted in the absence of any commercial or financial relationships that could be construed as a potential conflict of interest.

Copyright (c) 2017 Lanfray and Richard. This is an open-access article distributed under the terms of the Creative Commons Attribution License (CC BY). The use, distribution or reproduction in other forums is permitted, provided the original author(s) or licensor are credited and that the original publication in this journal is cited, in accordance with accepted academic practice. No use, distribution or reproduction is permitted which does not comply with these terms. 